\title{
NARASI VISUAL KEMATIAN PADA ILUSTRASI BUKU CERITA RAKYAT ANAK INDONESIA
}

\author{
Refita Ika Indrayati, Pindi Setiawan, Acep Iwan Saidi
}

\begin{abstract}
Folklore used as a tool to transfer life lesson from generation to generation. In the midst of modern children's books that carry moral as a main theme, folklore must comes with a new adaptation to compete with other stories. This adaptation forced to change how sensitive theme must be delivered, such as death. This study aims to explore how Indonesian folklore books that narrated death in terms of images, texts, and relationships built between the two elements. Using content analysis, this research takes an example of story containing subtheme as story line from four printed books of Indonesian children's folktales that published between 2015-2017.
\end{abstract}

Keywords: visual narrative, death theme, children folktales

\section{PENDAHULUAN}

Cerita rakyat telah menjadi sarana pertukaran ilmu dari generasi ke generasi. Fungsinya yang memberikan pengetahuan seputar kehidupan menjadikann cerita rakyat digemari orang tua dan pengajar sebagai alat pengajaran tema moral dan budi pekerti pada anak. Cerita rakyat yang merupakan cerminan kehidupan bermasyarakat tentunya meng-hadirkan tema negatif yang ada dalam realitas kehidupan manusia. Salah satu tema negatif tersebut adalah kematian. Alhasil, tema tersebut juga terkandung dalam cerita rakyat yang dibukukan khusus untuk anak.

Peningkatan pengetahuan orangtua terhadap konten buku anak yang baik serta minat dan perhatian dari seluruh pemerhati buku anak berkontribusi pada perbaikan standar konten seluruh lini produksi literatur anak, termasuk cerita rakyat. Cerita rakyat yang termasuk dalam literatur anak, tentunya mengalami rekonstruksi sejalan dengan perubahan sosial yang terjadi di masyarakat. Tema-tema sensitif yang ada dalam buku cerita rakyat anak pun mengalami rekon- struksi untuk tetap mengakomodasi penyampaian budi pekerti sebagai bahan perkembangan kara-kter anak. Fenomena perubahan tersebut tentu-nya berkaitan dengan penggambaran ilustrasi dan teks yang disampaikan untuk menarasikan kema-tian.

Didasari permasalahan ini, pertanyaan yang ingin dijawab adalah bagaimana perupaan pada ilustrasi buku cerita rakyat yang menarasikan kematian dan bagaimana relasi yang terbentuk dari unsur perupaan tersebut.

Penelitian ini bertujuan mengkaji unsur dan cara kerja unsur perupaan ilustrasi buku cerita rakyat anak dalam menarasikan kematian serta mengkaji relasi dari unsur-unsur yang berperan dalam perupaan kematian. Dengan dikajinya unsur, cara kerja dan relasi yang terbentuk, penelitian ini diharapkan dapat memberikan manfaat dalam paparan objektif mengenai cara kerja narasi visual dalam menceritakan kematian pada buku cerita rakyat, memberikan perspektif baru dalam melihat dan membahas kematian dalam buku anak serta memperkaya 
bidang keilmuan Komunikasi Visual, khsususnya dalam ranah buku anak.

\section{METODOLOGI}

Penelitian ini menggunakan metode kualitatif dengan analisis konten yang berfokus pada penjabaran visual dalam ranah komposisi dan pe-maknaan visual. Teori yang digunakan berkaitan dengan cerita rakyat sebagai bagian dalam sastra anak serta pemahaman narasi dalam ranah visual sebagai ilustrasi dan struktur narasi teks. Pengum-pulan data dilakukan melalui kajian pustaka dan observasi terhadap buku cerita rakyat anak komersil.

Kriteria pemilihan sampel cerita berdasarkan kategori tahun terbit yaitu 2015-2017, jenis buku yang merupakan buku cerita rakyat Indonesia dalam bentuk kumpulan atau satuan, tema dan konten buku, serta konteks kematian yang dijabarkan dalam cerita. Berdasarkan kriteria ini dipilih sepuluh cerita dengan jenis dongeng dan legenda dari empat buku cerita rakyat komer-sil yang mewakili lima kategori tema kematian: 1) kematian tokoh minor sebagai penggerak alur cerita: Harta Terpendam dari Cerita Asli Nusa-ntara dan Enchanting Tales, 2)kematian tokoh utama sebagai bentuk pengorbanan: Nyale dari Cerita Asli Nusantara dan Putri Sedoro Putih dari Kumpulan Cerita Klasik Indonesia, 3) kematian tokoh utama sebagai bentuk kutukan: Malin Kun-dang dari Cerita Asli Nusantara dan Enchanting Tales, 4) kematian tokoh antagonis: Timun Mas dari Cerita Asli Nusantara dan Enchanting Tales, dan 5) kematian tokoh utama untuk melewati kesulitan hidup: Legenda Putri Duyung dari Seri Cerita Rakyat dan Putri Kandita dari Kumpulan Cerita Klasik Indonesia.

\section{DASAR TEORETIS}

A. Sastra Anak dan Cerita Rakyat

Sastra anak mencangkup segala sesuatu yang berkaitan dengan kehidupan anak, seperti kelahiran, kematian dan segala sesuatu diantaranya [1]. Cerita rakyat yang terdiri dari mitos, legenda, dongeng dan fabel adalah salah satu jenis sastra anak. Cerita rakyat yang dulunya ditu-turkan, seiring perkembangan zaman mulai dibu-kukan. Khusus untuk target anak, cerita tersebut diilustrasikan dengan penggambaran yang mena-rik. Pemerintah yang menekankan pentingnya pendidikan karakter dan pendidikan kebudayaan sejak era reformasi [2] membuat cerita rakyat Indonesia mulai dipasarkan untuk anak.

B. Narasi Visual dalam Ilustrasi Buku Anak

Narasi Visual adalah sebuah penyampaian cerita yang dilakukan melalui media dengan representasi gambar visual atau grafis, secara bergerak maupun diam. Karakteristik narasi visu-al adalah: 1) adanya satu cerita yang akan disam-paikan, 2) elemen visual untuk meng-komu-nikasikan cerita tersebut, 3) adanya aktor atau partisipan untuk menjalankan cerita, 4) narasi visual yang memiliki dunia tersendiri, dan 5) narasi visual dapat diaplikasikan dalam media apapun [3]. Narasi visual berfungsi membantu pengamat dalam memvisualisasikan cerita dalam berbagai media dimana narasi tersebut digunakan.

Buku anak merupakan media dari narasi visual yang berbentuk statis karena menggunakan gambar diam untuk menyampaikan informasi. Untuk itu, ilustrasi merupakan bagian penting dalam buku anak. Selain menyampaikan infor-masi, ilustrasi juga menjembatani kesen-jangan antara bahasa lisan dan tulisan dengan mende-finisikan karakter, mengembangkan alur cerita dan memberikan sudut pandang lain dari cerita [4], [5]. Ilustrasi yang digambarkan dalam buku anak harus berkaca pada elemen berikut: 1) komposisi objek: besar-kecil, warna, latar dan fokus, 2) perspektif: jauh-dekat, atas-bawah, dan 3) simbol visual: ide dari konstruksi sosial [6]. Ketiga elemen tersebut penting untuk memantik pemaknaan cerita pada pembaca berdasarkan 
pengalaman yang mereka miliki sehingga narasi visual yang dapat dirasakan secara maksimal.

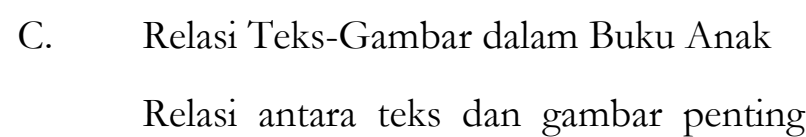
dalam kesinambungan dua unsur tersebut dalam buku anak. Nikolajeva dan Scott mengemukakan lima tipe relasi: 1) Simetri, dimana dua unsur berinteraksi secara redundan karena menjelaskan hal yang sama, 2) Perluasan atau enhancing, dimana narasi teks bergantung pada narasi visual atau narasi visual mendukung narasi teks, 3) Komplementer, dimana kedua unsur saling mengisi kekurangan satu sama lain, 4) Pertentangan atau counterpoint, dimana kedua unsur saling bergantung sehingga menimbulkan interpretasi lain dalam memaknai jalannya cerita, dan 5) Sile-ptik, dimana kedua unsur terpisah dan tidak bergantung satu sama lain [7],[8].

\section{HASIL KAJIAN DAN PEMBAHASAN}

\section{A. Visualisasi Kematian}

Penggambaran ilustrasi untuk memaparkan kematian berbeda-beda pada setiap cerita. Aspek visualisasi ini berhubungan dengan baga-imana tokoh meninggal dunia dan cara penggam-barannya. Konteks penyampaian kematian sen-diri terbagi menjadi dua yaitu kematian klinis yang berkaitan dengan kematian tubuh secara biologis dan konteks kematian non-klinis yang berkaitan dengan kematian tokoh karena unsur magis. Dua konteks tersebut masing-masing memiliki peng-gambaran ilustrasi yang berbeda yang didukung dengan penggunaan skema warna pada masing-masing buku.

Pada konteks kematian klinis, jenis penggambaran yang ditemukan adalah tersurat (fisik tokoh digambarkan mati secara langsung), dan tersirat (absennya karakter dalam penggambaran kematian atau pergantian fisik tokoh dengan ben-da yang berkaitan dengan simbol kultural kema-tian). Sedangkan pada konteks kematian non-kli-nis, jenis penggambaran yang ditemukan adalah transformasi (kematian fisik dengan berubah ke objek lain, baik makhluk hidup maupun benda mati) dan tranposisi (kematian fisik dengan cara berpindah dunia). Jenis penggambaran tersebut tersebar dalam lima kategori tema cerita kema-tian.

Pada konteks visualisasi kematian, aspek warna yang digunakan dapat berpengaruh pada keseluruhan suasana yang digambarkan. Dari ana-lisis, seluruh sampel buku anak menggunakan warna dengan saturasi cerah, bahkan pada peng-gambaran kematian. Penggunaan warna tersebut membawa tema kematian yang suram menjadi lebih positif. Contoh perbandingan skema warna pada satu cerita yang diambil dari masing-masing buku dapat dilihat dalam gambar 1 .

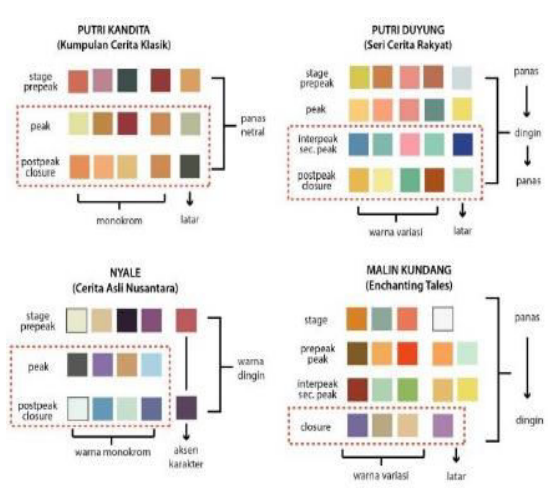

Gambar 1. Perbandingan warna ilustrasi (dalam kotak garis putus-putus) dengan skema keseluruhan warnapada empat sampel cerita rakyat

Sementara dari analisis penyampaian kon-teks kematian ditemukan bahwa visualisasi kema-tian klinis didominasi oleh penggambaran secara tersurat, sedangkan dalam kematian nonklinis didominasi oleh penggambaran tranformasi (non-klinis). Jika ditarik lebih jauh lagi, dominasi dari masing-masing penyampaian konteks kema-tian pada buku cerita rakyat Indonesia memiliki pola yang berulang. 
Dalam konteks kematian non-klinis (tran-sformasi dan transposisi), penggambaran kema-tian masing-masing dibagi menjadi dua

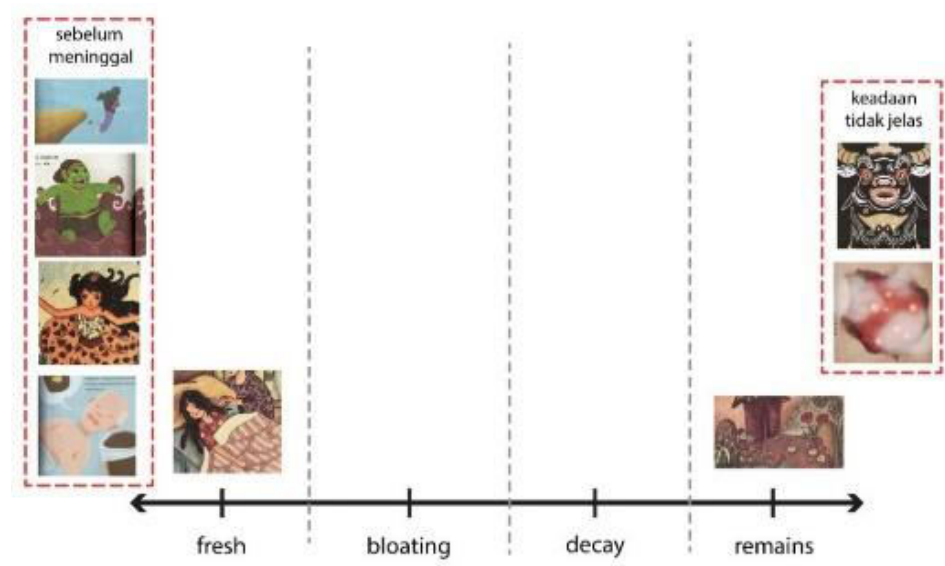

Gambar 2. Seluruh ilustrasi kematian klinis dalam skala penguraian tubuh

\section{a. Kematian Klinis}

Dalam konteks kematian klinis (tersurat dan tersirat), tokoh yang meninggal lebih banyak digambarkan pada adegan sebelum meninggal atau dalam keadaan dekomposisi tubuh yang ti-dak jelas. Sehingga kecenderungan visual klinis dapat dibagi menjadi dua gaya penggambaran: 1) menggambarkan apa yang menyebabkan dan bagaimana tokoh meninggal, bukan apa yang ter-jadi setelah tokoh minggal (dalam peng-gambaran tersurat), 2) tidak menggambarkan tubuh tokoh namun diganti menjadi fokus objek lain yang ber-hubungan dengan kematian tokoh (dalam peng-gambaran tersirat).

\section{b. Kematian Nonklinis}

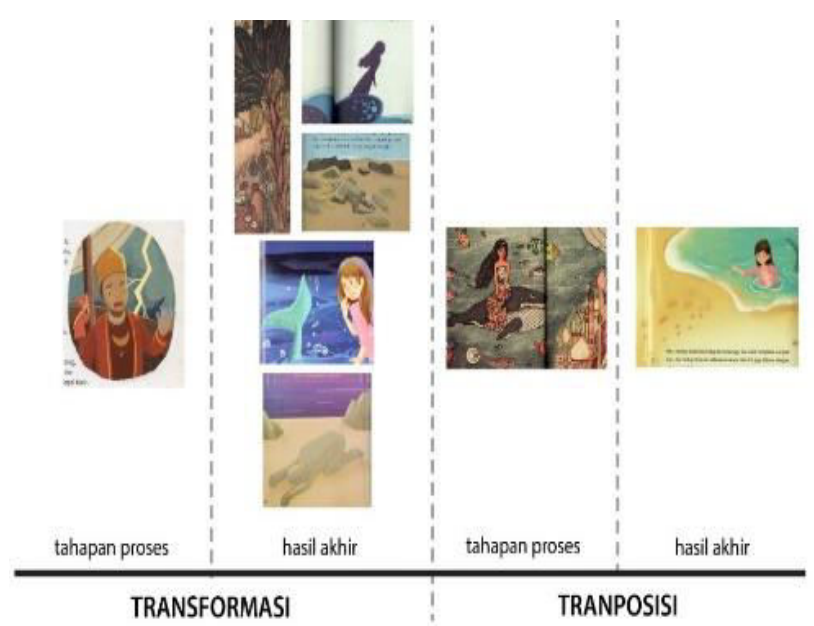

tahap, yaitu tahapan proses dan hasil akhir. Visualisasi transformasi didominasi penggambaran hasil akhir dimana karakter telah berubah wujud. Sem-entara tranformasi dengan gambar proses dan kedua penggambaran transposisi digunakan se-cara merata. Khusus pada penggambaran ilustrasi dengan cara transformasi, kematian ditekankan dengan menunjukkan hasil akhir perubahan kara-kter menjadi objek lain ketimbang prosesnya.

B.

\section{Kematian}

Penggunaan Teks Deskripsi

Teks untuk mendeskripsikan kematian dalam buku cerita rakyat dapat dibagi menjadi dua tipe: eksplisit (proses transformasitranposisi, jab-aran fisik tokoh saat menemui ajal, serta kejadian aksi-reaksi) dan implisit (jabaran kematian secara metaforik, terdiri dari suasana, keinginan, hara-pan dan perasaan tokoh).

Dalam sepuluh cerita yang dianalisis, penggunaan teks secara eksplisit lebih banyak digunakan. Lebih spesifik lagi, teks secara eksplisit tersebut menjabarkan proses trans-formasi dan transposisi. Sementara teks implisit yang tersebar secara merata lebih banyak menjelaskan suasana, sepertiperubahan cuaca sebagai penandaan karakter Tuhan untuk mendukung proses Jurnal Budaya Nusantara Vol. 2 No. 1 | 207
Gambar 3. Visualisasi tokoh dalam kematian non-klinis secara transformasi dan tranposisi 
transformasi dan jabaran metaforik kematian dengan tranposisi.

\section{Relasi Teks-Gambar}

Delapan dari sepuluh cerita yang dikaji dalam penelitian ini mengambil satu bagian dari teks dan menggambarkannya sesuai dengan apa yang tertera dalam narasi teks tersebut. Karena kedua unsur menjelaskan hal yang sama, ilustrasi dan teks kematian pun lebih banyak disampaikan dengan relasi simetri. Dari hasil tersebut dapat disimpulkan bahwa relasi yang terbentuk tidak tergantung pada tema cerita atau konteks kematian ditawarkan, namun lebih kepada bagaimana ilustrasi digambarkan dan narasi teks yang mengi-kutinya. Penggambaran karakter dalam ilustrasi dan penyampaian pesan dalam bentuk teks ber-peran penting pada relasi yang terbentuk. Hal ini sepenuhnya berada di tangan kreator, yaitu penulis dan ilustrator.

\section{SIMPULAN}

Ilustrasi merupakan bagian yang tak dapat dipisahkan dari buku anak karena fungsinya seba-gai perpanjangan teks. Selain itu, ilustrasi juga da-pat membantu mengomunikasikan tema yang dianggap negatif seperti kematian.

Dalam cerita rakyat Indonesia, unsurunsur visualisasi kematian bekerja dengan cara penghalusan. Hal ini ditandai dengan peng-gambaran kematian secara metaforik, yaitu tidak ditemukannya penggambaran dekomposisi tubuh serta penggunaan warna dengan saturasi cerah untuk menggambarkan kematian. Namun dalam konteks isi, deskripsi kematian cenderung lebih lugas, terutama pada proses perubahan dalam konteks kematian non-klinis.

Dalam konteks masyarakat tradisional, kehidupan nyata selalu bercampur dengan hal tidak nyata (magis atau gaib). Hal tersebut tercermin pada cerita tradisional yang tidak memisahkan unsur hidup dan mati, sehingga kematian menjadi satu peristiwa yang biasa. Namun, pada konteks masyarakat modern, kehidupan dan kematian adalah dua unsur yang terpisah. Kematian dipahami sebagai akhir kehidupan, sehingga keb-eradaanya menjadi sesuatu yang luar biasa. Kar-ena sifatnya yang final, kematian seringkali diper-sepsikan secara negatif.

Buku cerita anak, termasuk adaptasi modern cerita rakyat, adalah rekonstruksi dunia anak menurut sudut pandang orang dewasa. Penghalusan unsur ilustrasi yang bertentangan dengan teks berperan untuk menegasi kesan lugas sehingga tema kematian yang dekat dengan kese-dihan, ketakutan dan kecemasan menjadi lebih positif serta dianggap cocok untuk konsumsi anak-anak.

\section{DAFTAR PUSTAKA}

Sarumpaet, R.

2010 Pedoman Penelitian Sastra Anak. Jakarta: Pusat Bahasa Kementrian Pendidikan Nasional.

Masykuroh, Q.

2016 Old Bodies in New Clothes : Indonesia Folktales in Children's Books. "Diseminasi Luaran Riset dan Pengabdian untuk Indonesia Berkelanjutan' The 3rd University Research Colloquium (URECOL), 130-136.

Pimenta, S. dan Poovaiah, R.

2010 On Defining Visual Narratives. Design Thoughts.

Fang, Z

1996 Illustrations, Text, and the Child Reader: What are Pictures in Children's Storybooks for? Reading Horizon, 37(2), 131142.

Elster, C., \& Simons, H.

1985 How Important are Illustration in Children's Readers? The Reading Teachers, 148-152.

Serafini, F.

2011 Expanding Perspectives for Comprehending Visual Images in Multimodal Texts. Journal of Adolescent \& Adult Literacy, 54(5), 342-350.

Nikolajeva M. dan Scott,C.

How Picturebooks Work. New York : Routledge, Taylor \& Francis Group.

Sipe, L. 
2012 Revisiting the Relationships Between Text and Pictures. Children's Literature in Education, 43, 4-21. 